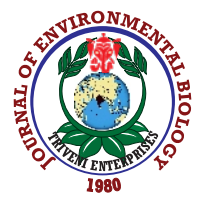

\title{
Agricultural crops common in the Chorokhi and Mtkvari upstream according to the Old Turkish Census Books
}

\author{
D. Sartania', D. Nikolaishvili", A. Ujmajuridze ${ }^{1}$ and M. Kvetanadze ${ }^{1}$ \\ 'IvaneJavakhishvili Tbilisi State University, Museum of TSU, Tbilisi, 0179, Georgia \\ ${ }^{2}$ IvaneJavakhishvili Tbilisi State University, Faculty of Exact and Natural Sciences, Department of Geography, Tbilisi, 0179, Georgia \\ ${ }^{3}$ IvaneJavakhishvili Tbilisi State University, Shota Rustaveli Institute of Georgian Literature, Tbilisi, 0179, Georgia \\ ${ }^{4}$ IvaneJavakhishvili Tbilisi State University, Faculty of Exact and Natural Sciences, Department of Geography, Tbilisi, 0179, Georgia \\ *Corresponding Author Email : dali.nkolaishvili@tsu.ge
}

\begin{abstract}
Aim: The main aim of the research was to give a retrospective picture of the agricultural crops growing in the upper reaches of the Chorokhi and Mtkvari
\end{abstract} Rivers based on Old Turkish registers.

Methodology: The present study is mainly based on the historical sources - the Old Turkish Census Books, drafted by Ottoman authorities, such as: The Grand and Brief Books, which were translated in Georgian. These documents are interesting as they incorporate interesting and valuable information for different branch specialists: rich social-economic, demographic, administrative, agricultural, paleographic, linguistic, toponymic and family-andheritage materials. They give a real picture and in fact, describe the situation at the moment of censuses quite accurately. The research was based on obtaining, systemization and listing various scientific sources, identification of the objects. For this purpose, the published, archive and fund materials were used.

Results: A retrospective picture of the branches of economy in the study area became possible to create by considering the amount of taxes to the agricultural crops and the growing areas of the crops. However, during identification of the peculiarities of territorial distribution of agricultural crops, analysis of other circumstances also played an important role, in particular, the tax amount per household not only for agricultural crops, but also for their production (mill, oilery), etc. The study demonstrated that grain-growing was a leading branch in the study area and the major agricultural crops were: wheat, barley, rye, panic grass, chick-

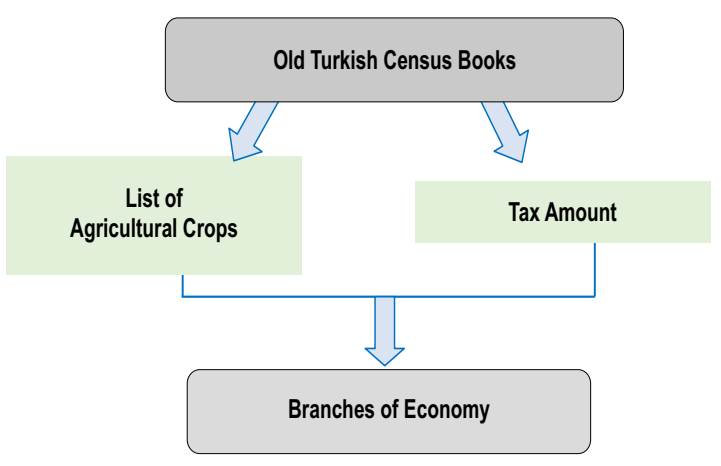
pea, lentil. They also grew walnut, different fruits and vine varieties. The two latter cultures were quite commonly grown in Nahiyesis and villages, among other things evidenced by high taxes and "shira" (sweet juice) taxes. The most commonly grown crop was wheat. This evidences that wheat was the main agricultural crop, or used most of all in the people's food ration. They also grew technical crops (lint, hemp and cotton) and paid taxes for processing them.

Interpretation: The comparison of gained results with modern agrobotanical and ethnological studies show that then-time traditional structure of agriculture in the study area has not changed essentially and has preserved the principal features of specialization. However, today, besides wheat, other agricultural crops (nut, tea, etc.) are also used.

Key words: Agricultural crops, Gurjistan Governorate, Old Turkish Census books

How to cite : Sartania, D., D. Nikolaishvili, A. Ujmajuridze and M. Kvetanadze: Agricultural crops common in the chorokhi and mtkvari upstream according to the Old Turkish Census Books. J. Environ. Biol., 41, 421-425 (2020). 


\section{Introduction}

Historical-geographical and historical-cartographic studies play an important role in creating a retrospective picture of the past. Without studying the past, it is impossible to gain an indepth insight in the political, social or economic peculiarities of modern times, if not talking about forecasting the future. These studies have a long history; however, there is still a series of questions unanswered till date. Unfortunately, most studies are focused on a single discipline - on history and do not highlight the questions concerned with other fields and also at the intersection of different sciences, neither do they make use of modern technologies.

In the $16^{\text {th }}$ century, the Turkish government provided a census of the basin of the upper reaches of the Chorokhi and Mtkvari Rivers several times. Some parts of the censuses are still available till date, including the followings mentioned below:

The Grand Book of Gurjistan Governorate", dated 1574, translated from Turkish into Georgian by N. Shengelia (2016); The Grand Book of Gurjistan Governorate", dated 1595, translated from Turkish into Georgian by S. Jikia (1941); Jaba Grand Book of Childir Governorate", dated 1694-1732, translated from Turkish into Georgian by Ts. Abuladze (1979) and A Brief Book of Childir Governorate", translated from Turkish into Georgian by M. Makharadze and N. Shengelia (2008).

These documents are interesting as they consist of interesting and valuable information for different branch specialists: rich social-economic, demographic, administrative, agricultural, paleographic, linguistic, toponymic and family-andheritage materials. As these materials are censuses of the population of the settled areas by Ottoman State, they give a real picture and in fact, describe the situation at the moment of censuses quite accurately. This is why it is an original reliable source for different branch specialists. However, due to nonsystematized information, it is virtually unavailable for them. In addition, the single branches of economy and agricultures spread here in the past do not exist at present. Therefore, studying this topic is very interesting, as it will help us to establish the questions of traditional nature use and find out the forgotten traditional knowledge.

In view of the above the aim of this study was to give a retrospective picture of the agricultural crops growing in the upper reaches of the Chorokhi and Mtkvari Rivers based on old Turkish registers.

Till date, only some questions of the Old Census Books have been studied, and besides, by the historians only. Some of such questions are: Ottoman taxes and firmans [Shengelia, 1960, 2008, 2016; Tivadze, 1946], administrative division and general socio-economic situation [Svanidze, 1999]. These studies mostly deal with the general analysis of governorates as of whole territorial units without identifying the territorial differences between them, while a governorate covers quite a large area with diversified physical-geographical, socio-economic and cultural features. The present study will not only give a general, but a detailed picture by showing the internal territorial differences of the areas.

Virtually, these Old Census Books have never been studied with respect to geography or cartometry. The advantage of the paper is also evidenced by its orientation mostly on retrospective mapping and geographical-cartometric analysis of the Old Census Books. In particular, these scientific novelties are: Creating a retrospective picture of socio-economic state-according to the level of economic development, distribution of agricultural crops, developing new varieties (Pande et al., 2016); identifying traditional kinds of natural management; creating GIS and thematic maps and territorial analysis.

\section{Results and Discussion}

As the Turkish registers show, in the $16^{\text {th }}$ century, four levels of administrative planning of the territory were used in the Ottoman Empire: Governorate $\rightarrow$ Liva/Sancak $\rightarrow$ Nahiyesi (district) $\rightarrow$ village. Gurjistan Governorate itself was divided into 9 Livas and 37 Nahiyesis. These Livas were (Fig. 1): Akhaltsikhe (I), Khertvisi (II), Akhalkalaki (III), Chrdili (IV), Potskhovi (V), Petre (VI), Didi-Artaani (VII), Panaki (VIII) and Oltisi (IX). The largest areas were occupied by Oltisi and Akhaltsikhe Livas, while the smallest areas were occupied by Petre and Potskhovi Livas. The Nahiyesi are distributed unevenly across the Livas. Oltisi Liva was located in the upper reaches of the Oltisistskali River and its tributaries. Its area was $3415 \mathrm{~km}^{2}$ making $22.5 \%$ of the total area of the Governorate. This Liva included 9 Nahiyesis: Mzvare, Misrasori, Chrdili, Bardusi, Andzavi, Arasdi, Oltisi, Janusori and Akha. Due to incomplete data of the Register, the borders of these Livas are not identified and are not plotted on the map as a result.

The area of Gurjistan Governorate was $15204 \mathrm{~km}^{2}$ and the number of settled areas was more than 1600 . There are several deserted villages; however, taxes were imposed on some, as people from other villages used the lands. Consequently, the data included in the Register helped in identifying the socio-economic situation of that time.

Analysis of the objects given in Great Map of Gurjistan Governorate (Aslanikashvili, 1953).

Land tenure and tax system : During that period, people used various types of land tenure, which can be classified in four types [Essays of Georgia History, 1973; Otkhmezuri, 1973]: State lands - Miri; Feudatory lands, which were divided into Timar, Ziamet, Khas; Privately owned lands - Temlik and Mülk; Wakf lands, and Communal land property (of individual plots only). 
Nahiyah and Lives

Akhaltsikhe Nahiyah (District) :

1. Mzvare, 2. Cridili, 3. Ude, 4. Kvabsliani

5. Atskuri, 6. Okrostsikhe, 7. Otskhe

8. Aspindza, 9. Chacharaki

Khertvisi Nahiyah (District) :

10. Khertvisi, 11. Tkiani Javakheti

12. Byzmareti

Akhalkalaki Nahiyah (District) :

13. Akshehiri, 14. Tmogvi, 15. Nialiskuri

Akhalkalaki Nahiyah (District) :

16. Janbazi, 17. Kanarbeli

18. Mgcltsikhe

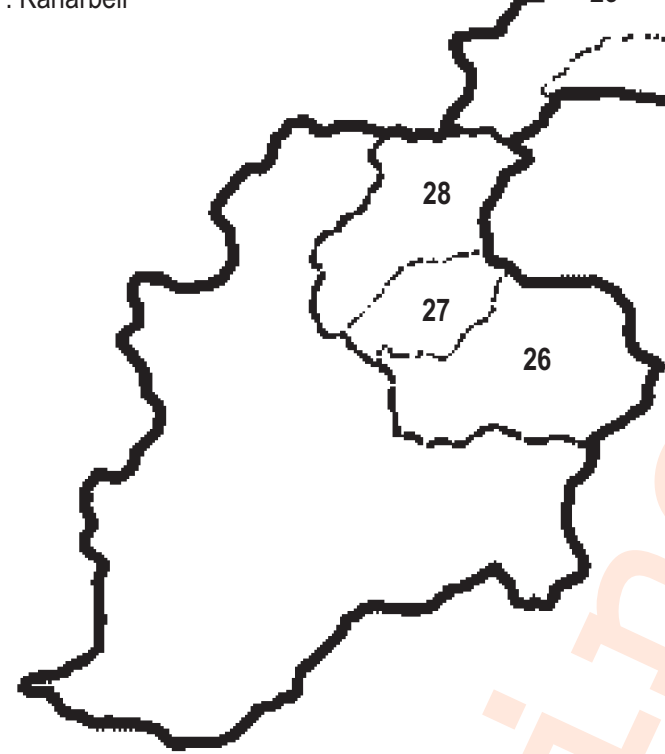

Fig. 1 : Administrative Division of Gurjistan Governorate (1595).

Majority of the lands belonged to state and a formal owner of all lands was Sultan [lbragimov, 1953]. Therefore, it was prohibited to buy, sell and present lands. Usually, the land estates were settled with peasants, who received the right to use the land in two ways: by heredity. However, this title was limited and strictly defined. As a rule, the land was given out to the entities valid for military service and was not passed on by heredity, even to women or disabled, even if they were the children of a land owner. It is true that some land areas were passed on by heredity, but this right did not survive across all generations. A land plot could be passed on from father to son, but a grandson had to obtain it from his grandfather by virtue of a Tafu, meaning that among other taxes, a grandson had to additionally pay "a single duty to register the land plot a new" [Tivadze, 1946].

A tax system was very complex and diversified. Taxes were imposed for every village and land plot and their total number was 12 or 13 , and even 15 for some villages. The number of taxes for small settlements was only 5 to 10 .

The taxes were paid both, with monetary units (akçe) and in kind (Qila - a measuring jug for different foods). There were other taxes, too. Qila was used in Gurjistan Governorate as well, as a unit of payment (unit of weight) for wheat, barley, rye, walnut, etc. For instance, according to the "register of 1595", village Sairmia (in AkhaltsikheLiva, UdeNahiyesi) paid 100 jars for wheat and barley each, 15 jars for rye, 10 jars for panic grass, 3 jars for horse bean, 2 jars for lentil and flax seeds each and 1 jar for beans. The size and weight of Qila varied across the regions and history. During wars, 1 jar of wheat was sold at 1000 akçe and 1 jar of barley was sold at 800 akçe.

Ashar was a tax imposed for agricultural products and equaled to $1 / 10$ of one's income. It was of two types: the first was 
Zakat, or the tax imposed for a land plot, and another was Ashar equaling to one-tenth of the harvest gained from the land and it was one of the Haraç taxes (a land tax levied on non-Muslims). If the land gave two harvests, the tax was consequently levied twice. Often, a peasant was made pay a half of its harvest. Ashar, as a tax, was imposed for all branches of agriculture and mostly, it was levied in kind, but sometimes as money, as well. Ashar was one of the most common taxe of that time.

Virtually, all agricultural crops grown by the local people were taxed: cereals (wheat, barley, rye, panic grass), legumes (chick-pea, lentil), walnut, fruit, vine, flax, etc. Concrete agricultural species were hardly found at any source. It is also interesting that some agricultural crops were spread so widely that were used to make "shira" (non-alcoholic drink made from slightly fermented grape juice); people had mills and taxes were also imposed on them. The amount of taxes given in the registers make it clear that the main cereals were wheat and barley.

Barley was most common agricultural crop grown at 200$2400 \mathrm{~m}$ above sea level, virtually being the only crop near the uppermost hypsometric limit of land cultivation. According to Iv. Javakhishvili's view, Second to wheat, common barley and barley were the most important nutrient plants for people [Javakhishvili, 1996]. Barley was grown mainly due to two reasons; firstly it is drought- and frost-resistant crop, but did not require high humidity. It grows rapidly at the initial stage of vegetation period. During this period, it efficiently uses summer moisture what makes it drought-resistant. Relatively dry climate and low temperature in Meskheti region helped to grow barley successfully at high hypsometric altitudes in the region and gain rich harvest, and secondly versatile use of barley (for nutrition, curative, ritual and other purposes. There is another important fact regarding barley - the grains were used in the New-Year ritual [Makalatia, 1938].

The total tax for barley in Gurjistan Governorate was 298 523. The local people paid 5 akçe for 1 jar (Qila) of barley. Akhaltsikhe paid the highest tax for barley among eight Livas, while PetreLiva paid the least. In Akhaltsikhe Liva, Chacharaq Nahiyesi ranked first for paying barley tax (15180 jars), while Kvabliani Nahiyesi ranked the last (with 1820 jars).

Wheat was one of the major agricultural crops. The local people paid a tax of 7 akçe for 1 jar of wheat what was higher than the taxes for other cereals (barley, panic grass, rye). Wheat was sown over the largest areas as compared to other cereals. The tax for wheat as for the agricultural crop was imposed on almost all villages. For instance, the total tax for wheat in Gurjistan Governorate was 279091 akçe. Akhaltsikhe paid the highest tax for wheat among eight Livas, while PetreLiva paid the least for wheat.

Rye and panic grass were one of the most important agricultural crops grown in Gurjistan Governorate. Akhaltsikhe
Nahiyesi was prominent with these crop, too, like Khertvisi Liva. For instance, the tax for rye in one village (Diltska) was only 500 jars. Petre Liva seemed not to grow rye at all. Ude Nahiyesi of Akhaltsikhe Liva had posed the highest tax for panic grass (1552 jars) among nine Nahiyesis, while Kvabliani region paid the least for this cereal (20 jars). Chrdili and ArtaaniLivas did not have panic grass tax at all.

The situation was similar with respect to legumes. Legumes occupied the greatest areas in Akhaltsikhe Liva. However, they occupied much less areas than cereals. For instance, the tax for lentil was imposed on two Livas only (Akhaltsikhe and Khertvisi). Besides, only two of twenty-five villages in Otskhi Nahiyesi (AkhaltsikheLiva) paid tax for lentil.

Vine was one of the most common crops as evidenced by two major circumstances: naming of vineyards and taxes imposed on them, which give us an idea about the sizes of the vineyards, and tax for "Shıra" (sweet juice), which was usually made of grapes (but sometimes with other fruits as well). Therefore, the tax for "shira" is an indirect indication of a cultural vine-growing. For example, G. Tivadze, based on the "register of 1595", named 144 villages in Gurjistan Governorate where the local people grew vine [Tivadze, 1946]. The comparison of these data with the "Register" made it clear that G. Tivadze made this conclusion by relying not only on the vineyard tax, but also on "shira" tax. By using a similar approach, we calculated the total number of such villages in Gurjistan Governorate which is 158 .

People must have grown vine in other villages of Gurjistan Governorate as well. However, this fact is not given in the "Register". Here, the villages "out of Register" are meant in the first instance, which, owing to various state offices, did not pay the effective taxes of the Governorate. As evidence, we can cite the fact that some villages known for traditional vine-growing from the ancient past (as evidenced by artificial terraces, survived Kvevri jars (clay wine pitchers), wine presses, wilding vine roots, etc., were not charged for vineyard or "shira" tax. Such villages were Boga, ZedaVardzia, Vargavi, Muskhi, Chobareti and others.

The taxes for the vineyards and "shira" are given in various combinations for different villages. Such combinations show the way a farmer used the gained harvest: as wine, fruit, raisin or juice, or if he made some other product of it. We can suppose that if grape was used as fruit and raisin only, people would have been charged with vineyard tax only; if people made juice with grapes as well, then tax would have been leived for both - vineyard and juice, and if they made only juice with the grapes, the tax would have been for "shira" only. The highest tax for "shira" was 1500 jars. Such villages were the ones of Khertvisi Liva: Toloshi and Pia (paying 1500 jars each). Panak Liva in the southern part of the Governorate is also interesting, where the tax levied for "shira" in village Norbeti was 1000 jars. 
Table 1: Number of villages charged with vineyard tax

\begin{tabular}{lc}
\hline Nahiyesi (district) & Vineyard tax \\
\hline Akhaltsikhe, Khertvisi & $>30$ \\
Chacharaki & $20-30$ \\
Kvabliani, Kanarbeli, Mzvare & $10-20$ \\
Ude, Atskhuri, Aspindza & $5-10$ \\
Otskhe, Khertvisi, Tkiani Javakheti, Buzmareti, Akshehiri, Tmogvi, Nialiskuri, Janbazi, Kanarbeli, Mgeltsikhe & $<5$ \\
\hline
\end{tabular}

In many villages, the population paid the tax for vineyard and "shira" at the same time. There were total 66 such villages in Gurjistan Governorate. In these villages the local people used grapes to eat and made juice of it. In some villages, they paid vineyard tax only and did not pay "shira" tax. This means that the vineyards in these villages did not occupy great areas, or the grapes did not yield rich harvest enough to make juice, e.g. in the villages of Mzvare Nahiyesi in Akhaltsikhe Liva: Boga, Agara near village Eliatsminda, Kheoti and others, the local people of some villages paid tax for "shira", but did not pay tax for vineyard, presumably because they did not have it.

Out of 28 Nahiyesis in Gurjistan Governorate, 19 villages levied vineyard tax. Such villages were particularly many in numbers in Khertvisi and Akhaltsikhe Livas amounting to 39.3 and $30.0 \%$ of the total number of the villages of the Livas, respectively, i.e., approximately $1 / 2$ of the villages of the given Livas paid vineyard tax. It is quite a high indicator and evidences that vinegrowing was a leading agricultural branch there. Next ranked Chacharaki Nahiyesi with about 1/5 of the villages paying the vineyard tax. As for other Nahiyesis, less than $10 \%$ of the total number of villages in each Nahiyesi paid the vineyard tax (Table 1).

In some cases, (e.g. in Aspindza Nahiyesi of Akhaltsikhe Liva), people possessed both vineyards and fruit gardens, but nothing is said about "shira" tax. They did not pay it and this indicates size of the gained harvest, suggesting that people led traditional life. As it seems, vine was grown at many locations of Gurjistan Governorate, though unevenly. Particularly large areas of vineyards were fixed in Akhaltsikhe Liva in Atskuri and Aspinda Nahiyesis in particular. They grew vine in 102 villages of Aspindza Nahiyesi. The Register does not give the names of vine species; however, data about the territorial distribution of vine allows gaining a good retrospective picture. The study showed that the major branches of farming were growing grains, legumes, vines and cattle-breeding. On comparing this picture to the presentday situation, we will see a big difference in the farming structure. Growing grain is still continued in some regions, though cattlebreeding is more popular, or it is substituted with other agricultural crops.

The highest taxes for agricultural crops were paid by Akhaltsikhe Liva due to dense settlements and high density of the local population. On the other hand, this fact is the evidence of favorable conditions to grow agricultural crops. This view is consolidated by the modern ethnographic data as well: this region is a leading producer of cereal crops even today.

\section{Acknowledgment}

This work was supported by Shota Rustaveli National Science Foundation (SRNSF) [\#HE-18-448, Geo-information Mapping and Analysis of the Georgian Cultural Heritage of SouthWest Georgia according to the Old Turkish Census Books].

\section{References}

A Brief Book of Childir Governorate: The text in Turkish was published and the translation, study, comments and foreword in the Georgian language were attached by NodarShengelia by M. Makharadze and N. Shengelia. Tbilisis, 2008.

Aslanikashvili, A.L.: Map of Gurjistan Governorate, Tbilisi, 1953, Edited by S. Jikia. Scale 1:300,000 Essays of Georgia History, IV, 131132 (1973).

Ibragimov, G.I.: Krestyanmkta uprisings in Tkrtsii in the XV-XVI centuries. Byzantine Vremenik, Vol. VII, Peterburg, pp. 122-145 (1953).

Jaba Grand Book of Childir Governorate (1694-1732): The text in Turkish was published and the translation, study, comments and foreword in the Georgian language were attached by NodarShengelia by Ts. Abuladze. Tbilisi (1979).

Javakhishvili, I.: Economic history of Georgia. Tbilisi (1996).

Makalatia, S.: Meskhet-Javakheti. Tbilisi (1938).

Otkhmezuri, T.: Turkish taxes in Kartli, 1723-1735 // Georgian Academy of Science, \#4, 18-33 (1973).

Pande, P.C., Vibhuti, P. Awasthi, K. Bargali and S.S. Bargali: AgroBiodiversity of Kumaun Himalaya, India: A Review. Curr. Agricult. Res. J., 4, 16-34 (2016).

Shengelia, N.: Turkish taxes and obligations according to The Grand Book of Gurjistan Governorate. // Collection of Papers of TSU, Tbilisi, pp. 277-304 (1960).

Svanidze, M.: From the History of the Relationship between Georgia and Ottoman Empire in the XVI-XVII centuries, Tbilisi (1999).

The Grand Book of Gurjistan Governorate (1574): The text in Turkish was published and the translation, study, comments and foreword in the Georgian language were attached by NodarShengelia. Tbilisis, 2016. In Georgian.

The Great Register of Gurjistan Governorate (1595), vol. Il.: The text in Turkish was published and the translation, study, comments and foreword in the Georgian and Russian languages were attached by SergiJukia, Tbilisi, Georgian SRR, Academy of Sciences, Institute of Language, History and Material Culture, 1941.

Tivadze, G.: Ottoman dwarf and peasant revolts in the XVI century. Tbilisi (1946). 